\title{
DURATION AND QUALITY OF SLEEP IN SPRINT AND RECOVERY PERFORMANCES AMONG ELITE SWIMMERS
}

\author{
DURAÇÃO EQUALIDADE DE SONO NO DESEMPENHO DO SPRINT ENA RECUPERAÇÃO DENADADORES \\ DEELITE
}

\section{DURACIÓN Y CALIDAD DEL SUEÑO EN EL DESEMPEÑO EN EL SPRINT Y RECUPERACIÓN D NADADORESDEÉLITE}

\begin{abstract}
Marco Túlio de Mello' (ID (Physical Education Professional) Mário Antônio de Moura Simim (DD (Physical Education Professional) Fernanda Veruska Narciso' (ID (Physical Education Professional) João Paulo Pereira Rosa' (D) (Physical Education Professional) Dayane Ferreira Rodrigues' (iD (Physical Education Professional) Luísa de Sousa Nogueira Freitas' ${ }^{1}$ (iD) (Physiotherapist)

Jorge José Bichara² (DD (Physical Education Professional) Sebastian Rafael Dias Pereira² (ID (Physical Education Professional) Sidney Cavalcante da Silva ${ }^{2}$ (DD (Physical Education Professional) Sérgio Tufik ${ }^{3}$ (D) (Physician)

Andressa Silva' (ID

(Physiotherapist)
\end{abstract}

1. Universidade Federal de Minas Gerais, School of Physical Education, Physiotherapy and Occupational Therapy, Sports Department, Belo Horizonte, MG, Brazil.

2. Brazilian Olympic Committee, Rio de Janeiro, RJ, Brazil. 3. Universidade Federal de São Paulo, Department of Psychobiology, São Paulo, SP, Brazil.

\section{Correspondence:}

Marco Túlio de Mello. Escola de Educação Física, Fisioterapia e Terapia Ocupacional, Universidade Federal de Minas Gerais. Av. Antônio Carlos, 6627, Pampulha, Belo Horizonte, MG, Brazil. 31270-901.

tmello@demello.net.br

\begin{abstract}
Introduction: Circadian rhythms can impact athletes'sports performance, where the plateau occurs between 15 and 21 hours. Swimming is a peculiar case, as athletes perform training and final sessions in competitions at different times, as in the Rio2016 Olympic Games for example, where the semifinal and final competitions took place from ten o'clock at night. Objectives: (1) to present the protocol of an intervention performed with elite athletes of the Brazilian swimming team during the 2016 Olympic Games in Rio; (2) to find out whether the time at which the competitions were held affected the swimming performances of these athletes during the competition. Materials and Methods: Fourteen athletes of the Brazilian swimming team (males: $n=10 ; 71 \%$ and females: $n=4 ; 29 \%$ ) participated in the study. They were followed up during two preparation periods (baseline and intervention) for the 2016 Olympic Games in Rio during June and July 2016. During the competition, we recorded the Reaction Time (RT) and Competition Time (CT) of each athlete in different modalities. The intervention strategies used were light therapy and sleep hygiene. The values of RT at the starting block and CT were registered and conferred with the official results. Results: The athletes showed a decrease in the total time awake $(\Delta=-13 \%$; Effect size $[E S]=1.0)$ and sleep latency $(\Delta=-33 \%$; ES $=0.7)$, and an increase in total sleep time $(\Delta=13 \% ; E S=1.1 ; p=0.04)$ between the baseline and the period of the intervention, pre-competition. We identified an improvement in the RT ( $\Delta=-2.2 \%$ to $-1.0 \% ; E S=0.2$ to 0.5$)$ during the competition only for the athletes who participated in the competition finals. Conclusion: We conclude that the intervention carried out was effective in mitigating any negative influence of competition time on the RT and CT of elite athletes of the Brazilian swimming team. Level of evidence ll; Prospective comparative study.
\end{abstract}

Keywords: Sports performance; Athletes; Actigraphy; Chronobiology.

\section{RESUMO}

Introdução: Os ritmos circadianos podem exercer impacto no desempenho esportivo dos atletas, onde o platô ocorre entre as 15 e 21 horas. A natação é um caso peculiar, uma vez que os nadadores realizam sessões de treinamento e provas finais em competições em diferentes horários, como por exemplo, nos Jogos Olímpicos Rio2016, onde as competições semifinais e finais da natação ocorreram a partir das 22 horas. Objetivos: O presente estudo teve como objetivos: (1) apresentar o protocolo de uma intervenção realizada com atletas de elite da equipe de natação brasileira durante os Jogos Olímpicos Rio 2016; (2) identificar se o desempenho dos atletas de natação foi afetado devido aos horários das provas durante a competição. Materiais e Métodos: Participaram do estudo 14 atletas da equipe de natação brasileira (masculino: $n=10 ; 71 \%$ e feminino: $n=4 ; 29 \%$ ). Foi realizado acompanhamento dos atletas durante dois períodos de preparação (baseline e intervenção) para os Jogos Olímpicos Rio2016 nos meses de junho ejulho de 2016. Durante a competição, foi realizado o registro do Tempo de Reação (TR) e Tempo de Prova (TP) de cada atleta nas diferentes modalidades. As estratégias de intervenção utilizadas foram: terapia de luz e higiene do sono. Os valores de TR no bloco de partida eTP foram registrados e conferidos com os resultados oficiais. Resultados: Os atletas apresentaram decréscimo no tempo total de vigília $(\Delta=-13 \%$; Tamanho do Efeito $(T E)=1,0)$ e latência de sono $(\Delta=-33 \% ; T E=0,7)$, e aumento do tempo total de sono $(\Delta=13 \% ; T E=1,1 ; p=0,04)$ entre o baseline e o período de intervenção pré-competição. Nós identificamos melhorias no TR ( $\Delta=-2,2 \%$ à -1,0\%; TE $=0,2$ a 0,5) ao longo da competição somente para os atletas que participaram da fase final da competição. Conclusão: Concluímos que a intervenção realizada foi efetiva para minimizar qualquer influência negativa do horário da competição sobre o TR eTP dos atletas de elite da natação brasileira. Nível de evidência ll; Estudo prospectivo comparativo.

Descritores: Desempenho esportivo; Atletas; Actigrafia; Cronobiologia.

\section{RESUMEN}

Introducción: Los ritmos circadianos pueden ejercer impacto en el desempeño deportivo de los atletas, donde la meseta ocurre entre las 15 h y las 21 horas. La natación es un caso peculiar, ya que los nadadores realizan sesiones de entrenamiento y pruebas finales en competiciones en diferentes horarios, como por ejemplo, en los Juegos Olímpicos Rio 2016, en donde las competiciones semifinales y finales de natación ocurrieron a partir de las 22 horas. Objetivos: El presente estudio tuvo como objetivos: (1) presentar el protocolo de una intervención realizada con atletas de élite del 
equipo de natación brasileño durante los Juegos Olímpicos Rio 2016; (2) identificar si el desempeño de los atletas de natación fue afectado debido a los horarios de las pruebas durante la competición. Materiales y Métodos: Participaron en el estudio 14 atletas del equipo de natación brasileño (masculino: $n=10 ; 71 \%$ y femenino: $n=4 ; 29 \%$ ). Fue realizado acompañamiento de los atletas durante dos períodos de preparación (baseline intervención) para los Juegos Olímpicos Rio 2016 en los meses de junio y julio de 2016. Durante la competición, se realizó el registro del Tiempo de Reacción (TR) y Tiempo de Prueba (TP) de cada atleta en las diferentes modalidades. Las estrategias de intervención utilizadas fueron: terapia de luz e higiene del sueño. Los valores de TR en el bloque de partida YTP fueron registrados y verificados con los resultados oficiales. Resultados: Los atletas presentaron disminución en el tiempo total de vigilia ( $\Delta=-13 \%$; Tamaño de efecto (TE) $=1,0)$, y latencia del sueño $(\Delta=-33 \% ; T E=0,7)$, y aumento del tiempo total de sueño $(\Delta=13 \% ; T E=1,1 ; p=0,04)$ entre baseliney el período de intervención precompetición. Identificamos mejoras en el TR $(\Delta=-2,2 \%$ a - $1,0 \% ; T E=0,2$ a 0,5) a lo largo de la competición sólo para los atletas que participaron en la fase final de la competición. Conclusión: Concluimos que la intervención realizada fue efectiva para minimizar cualquier influencia negativa del horario de la competición sobreel TRy TP de los atletas de élite de la natación brasileña. Nivel de evidencia ll; Estudio prospectivo comparativo.

Descriptores: Rendimiento deportivo; Atletas; Actigrafía; Cronobiología.

\section{INTRODUCTION}

In human beings, the biological rhythms are observed in different physiological, mental, physical and behavioral processes. ${ }^{1-3}$ In the physiological process, these rhythms modulate the entire metabolism, influencing the development of strength, hormonal secretions, autonomous nervous system's activity, among others. ${ }^{4}$ Considering that circadian changes implicate in adjustments of the biological clock ${ }^{2}$ and the meaning of the circadian rhythms or its diurnal variations of approximately 24 hours, would also have an impact upon the sporting performance of athletes, amateurs or high performance athletes. ${ }^{1,2}$

The circadian variation on the sporting performance has been researched since the end of the 60's, with major emphasis from the 90 's. ${ }^{1}$ The consensus is that the majority of the physical performance rhythms reaches a plateau between 3:00 - 9:00 p.m.. ${ }^{1,5-7}$ At the end of afternoon or beginning of night, the body temperature, the strength and flexibility are in acrophase (major peaks), contributing to a better performance at this time. ${ }^{4}$ Additionally, the circadian rhythms may be influenced by external factors, called zeitgeibers, such as light and dark phases of the day, ${ }_{1}^{8}$ application of exogenous light, ${ }^{9}$ time of food ingestion and physical exercise, ${ }^{10}$ as well as the regular physical training in specific time. ${ }^{5,11}$

Among the sporting modalities, swimming is considered a peculiar case when one observes the influence of time to train and performance. Swimmers perform their first training session in the morning (for example, 6:00-8:00 a. m.) and another session at the end of the afternoon, between 4:00 - 6:00 p. $\mathrm{m} . .^{5}$ Results from different studies have indicated improvement on the times of sprint during the day ${ }^{5,12}$ with a peak at the beginning of the night. These daily variations oscillate from 3 to $21.2 \%$, depending on the tested population, on the muscle groups tested and on the experimental design. ${ }^{13}$ However, the circadian variation upon the psychomotor performance can also suffer the influence of other factors, such as sleep deprivation of restriction, 14,15 duration of the warming up, ${ }^{11}$ working time or time for familiar commitments. ${ }^{6}$

From the point of view of sporting competition, for the swimmers who competed in the modalities of 50, 100 and $200 \mathrm{~m}$, to participate in the finals of these modalities, they must swim in the elimination session during the morning and the semifinals during the period of afternoon/ night, of the same day. The swimmers classify for the finals, will have to compete during the afternoon/night of the following day. ${ }^{5}$ This fact made trainers and physical assistants to prescribe trainings that would coincide with the same time as the competitions were to take place. We must also point out that the competition timetable is, sometimes, defined to conform to the typical activities of spectators and TV audiences, in detriment of the athletes. ${ }^{13}$ An example of this happened during the last Olympic Games in Rio 2016, where the swimming semifinals and finals took place from 10:00 p.m. Concerning this, Rosa et al. ${ }^{7}$ pointed out the potential negative effects of the night competitions upon the sporting performance of the athletes during the Games. These authors recommended the development of specific activities for this competition, once these events during the night time have never occurred in the history of the Olympic Games. Therefore, the present study has two main objectives: (1) to present the protocol of the conducted intervention with the elite athletes of the Brazilian swimming team during the Olympic Games in Rio 2016; (2) to compare whether the time of the games interfered on the sporting performance of the athletes during the Olympic Games Rio 2016.

\section{MATERIALS AND METHODS}

We adopted, as inclusion criterion in the present study, only the Brazilian athletes of the swimming team, who participated, at least, in two phases (elimination and semifinals and/or finals) of the swimming games during the Olympic Games Rio 2016. This way, our sample was comprised by 14 athletes of the Brazilian swimming team (males: $\mathrm{n}=$ $10 ; 71 \%$ and females: $n=4 ; 29 \%$ ) with age averaging between $27.3 \pm 2.4$ years old. All athletes were fully informed of the risks associated with the experimental procedures, and provided written consent. The present study was approved by the Ethical Committee in Research of the Federal University of São Paulo - UNIFESP under the legal term 0294/11.

We followed up the athletes during both periods of preparation (baseline and intervention) for the Olympic Games Rio 2016 during the months of June and July, 2016. During the competition, we registered the RT and CT of each athlete in the different events and phases of the Olympic Games. The strategy of the adopted intervention altered the daily routine of the athletes in three hours.

The circadian preference or the athletes' chronotype was evaluated by the of the Horne and Östberg's Questionnaire, ${ }^{16}$ composed by 19 self-evaluating questions on which the individual must register his preferential times in routine situations of the daily life. Scores above 58 classify individuals as morning persons, below 42 as afternoon persons and from 42 to 58, as intermediate or indifferent persons.

To register the sleep-wake cycle, we used the actigraph (Phillips Respironics Actiwatch 2, Murrysville, PA, USA) in the non-dominant wrist of each athlete ${ }^{17}$ during 10 days. The data were registered, taped and transmitted to the software Actware. Posteriorly, the results of total time awake, total sleep time (TTS), sleep efficiency, sleep latency and awakenings were analyzed for each period of evaluation. 
Light therapy (or phototherapy) involves the exposition to light wavelengths for a determined period of time in a specific time of the day, allowing for a change of phase in the individual's circadian rhythms. ${ }^{18} \mathrm{We}$ used in the present study, glasses model Re-Timer ${ }^{19}$ with light $100 \%$ free of UV rays and 2,500 lux, at a distance of $5 \mathrm{~cm}$ from the eye. Additionally, a room of the Olympic District was adapted to receive the athletes for their light therapy. This room was characterized by: Light, 100\% free of UV rays with LED lamps (9,500 lumens) and environment with 10,000 lux. The time of exposition was of 30 continuous minutes, between 6:00 and 7:00 p. m., during the period of intervention and during the Olympic Games.

The strategy of sleep hygiene is a method utilized for the re-education of necessary habits for a good sleep night. 20,21 It refers to behavioral aspects, environment conditions and other factors that are related to sleep and that might promote better quantity and quality of sleep. ${ }^{21}$ The sleep hygiene strategies utilized in the present study were based on previous work with elite athletes ${ }^{20,21}$ and performed during 10 consecutive days. Therefore, the athletes followed the recommendations, such as: air-conditioned room, dark and silent; use of masks for eyes and ear plugs; strategic naps during the afternoon; avoid watching TV before sleeping, use of computer or cell phones in bed; create sleep routine, sleep and waking up always at the same time; avoid caffeine approximately 4-5 hours before sleeping; do not consume any liquid before going to bed; use of dark glasses after the training conducted during the light phase of the day.

The results of the swimming events of the selected athletes were organized taking into consideration the days and times of the competition. The values of RT on the starting block and $\mathrm{CT}$, were registered and conferred with the official results, displayed in the Rio2016's Swimming Results Book.

\section{Statistical analisys}

The results are shown by means of descriptive statistics (average \pm standard deviation, confidence interval [IC 95\%] and frequency distribution). We used the normality test (D'Agostino \& Pearson omnibus normality test) to verify the data distribution. The effect size (ES) was calculated based on the baseline results, as well as the percentage difference ( $\Delta \%)$. For comparison between RT and CT among the elimination phases versus semifinals, we used the pared $t$ test. The Anova test (repeated measures) was used to compare the results of RT and CT between the elimination phases versus semifinals versus finals. We considered $5 \%$ the probability of an error type I.

\section{RESULTS}

In relation to the athletes' chronotype, they were classified as indifferent ( $n=9 ; 64 \%)$, moderate morning $(n=3 ; 21 \%)$, morning $(n=1$; $7 \%)$ and moderate afternoon $(n=1 ; 7 \%)$. From the point of view of the evaluated periods of quantity and quality of sleep (Table 1), the athletes demonstrated a decrease in the total time awake $(\Delta=-13 \%$; $E S=1.0)$ and sleep latency $(\triangle=-33 \% ; E S=0.7)$ and increase in total sleep time $(\Delta=13 \% ; E S=1.1 ; p=0.04)$ between the baseline and the pre-competition period of intervention.

Table 2 shows the comparative results between the elimination phase versus semifinals for RT and CT.

There were no differences between the results of RT and CT when we compared the three phases of the competition. (Table 3)

Table 1. Results of the variables of quality and quantity of sleep in swimming athletes ( $n=14)$.

\begin{tabular}{c|c|c|c|c|c}
\hline & Baseline & $\begin{array}{c}\text { Pre- } \\
\text { competition }\end{array}$ & $\mathbf{P}$ & $\boldsymbol{\Delta}$ & ES \\
\hline Total time awake (hours) & $12: 09 \pm 1: 51$ & $10: 31 \pm 1: 18$ & 0.07 & $-13 \%$ & 1.0 \\
\hline TTS (hours) & $6: 30 \pm 0: 49$ & $7: 21 \pm 0: 47$ & $0.04^{*}$ & $13 \%$ & 1.1 \\
\hline Efficiency (\%) & $82 \pm 9$ & $85 \pm 13$ & 0.59 & $3 \%$ & 0.2 \\
\hline Latency (minutes) & $35 \pm 13$ & $24 \pm 20$ & 0.14 & $-33 \%$ & 0.7 \\
\hline Awakenings (minutes) & $42 \pm 16$ & $40 \pm 20$ & 0.86 & $-4 \%$ & 0.1 \\
\hline TTS = total sleep time: ${ }^{*} p<0.05$
\end{tabular}

Table 2. Results of the comparisons between the elimination phase and semifinals for Reaction Time and Competition Time in swimming athletes $(n=14)$.

\begin{tabular}{|c|c|c|c|c|c|c|}
\hline Variables & Phase & Average $\pm S D$ & $\mathrm{Cl} 95 \%$ & $\Delta$ & ES & t Test \\
\hline \multirow{2}{*}{$\begin{array}{l}\text { Reaction } \\
\text { Time (ms) }\end{array}$} & Elimination & $0.667 \pm 0.041$ & $0.645-0.689$ & \multirow[b]{2}{*}{$0.30 \%$} & \multirow[b]{2}{*}{0.05} & \multirow{2}{*}{$\begin{array}{c}t=0.243 \\
d f=15 \\
p=0,811\end{array}$} \\
\hline & Semifinals & $0.669 \pm 0.037$ & $0.649-0.689$ & & & \\
\hline \multirow{2}{*}{$\begin{array}{l}\text { Competition } \\
\text { Time (sec) }\end{array}$} & Elimination & $72.3 \pm 38.0$ & $52.05-92.55$ & \multirow{2}{*}{$0.33 \%$} & \multirow{2}{*}{0.01} & \multirow{2}{*}{$\begin{array}{c}t=1.730 d f=15 \\
p=0.104\end{array}$} \\
\hline & Semifinals & $72.5 \pm 38.0$ & $52.32-92.76$ & & & \\
\hline
\end{tabular}

Table 3. Results of the comparisons between all phases of the competition for Reaction Time and Competition Time in swimming athletes $(n=6)$.

\begin{tabular}{|c|c|c|c|c|c|c|}
\hline Variable & Phase & Average $\pm S D$ & $\mathrm{Cl} 95 \%$ & $\Delta$ & ES & Anova \\
\hline \multirow{3}{*}{$\begin{array}{l}\text { Reaction } \\
\text { Time (ms) }\end{array}$} & Elimination & $0.690 \pm 0.044$ & $0.644-0.736$ & \multirow{3}{*}{$\begin{array}{l}-1.2 \%^{a} ; \\
-1.0 \%{ }^{b} \\
-2.2 \%^{c}\end{array}$} & \multirow{3}{*}{$\begin{array}{l}0.2^{\mathrm{a}} \\
0.2^{\mathrm{b}} \\
0.5^{\mathrm{c}}\end{array}$} & \multirow{3}{*}{$\begin{array}{c}F_{(2,9)}=0.435 \\
p=0.643\end{array}$} \\
\hline & Semifinals & $0.682 \pm 0.038$ & $0.642-0.721$ & & & \\
\hline & Finals & $0.675 \pm 0.021$ & $0.653-0.697$ & & & \\
\hline \multirow{3}{*}{$\begin{array}{l}\text { Competition } \\
\text { Time (sec) }\end{array}$} & Elimination & $54.9 \pm 35.1$ & $18.0-91.7$ & \multirow{3}{*}{$\begin{array}{c}-0.36 \%^{\mathrm{a}} ; \\
-0.37 \%^{\mathrm{b}} ; \\
0 \% \mathrm{c}\end{array}$} & \multirow{3}{*}{$\begin{array}{l}0.6^{a} \\
0.6^{b} \\
0.0^{c}\end{array}$} & \multirow{3}{*}{$\begin{array}{c}F_{(1,5)}=1.110 \\
p=0.341\end{array}$} \\
\hline & Semifinals & $54.7 \pm 34.7$ & $18.2-91.2$ & & & \\
\hline & Finals & $54.9 \pm 35.1$ & $18.0-91.7$ & & & \\
\hline
\end{tabular}

${ }^{a} \triangle$ or $E S \%$ : semifinals in comparison to elimination phase; ${ }^{b} \Delta$ or $E S \%$; finals in comparison to semifinals; ${ }^{c} \Delta$ or $E S$ $\%$ : finals in comparison to elimination phase.

\section{DISCUSSION}

In the present study, we present the elaborated intervention protocol for the elite athletes of the Brazilian swimming team to conform to the new time of competition in the Olympic Games Rio 2016. Besides, we have also investigated if there were any differences between the RT and CT of the athletes in relation to their competition timetable. We identified improvement for the RT ( $\Delta=-2.2 \%$ à -1.0\%; ES $=0.2$ to 0.5 ) during the competition only for the athletes who participated in the finals of their competition. Our intervention (sleep hygiene) also offered improvement upon the variables of quality and quantity of sleep. Evidences point out that room light per se, associated with the use of smartphones, watching TV during the night may delay the sleep phase and reduce sleep quality as well as sleep quantity. In general, during the training days and transmeridian trips, as well as, before and during sporting competitions, the sleep time decreases and there are impairments upon the sleep quality and the sporting performance as well. ${ }^{14,22}$ This was also demonstrated in the athletes of the present study during the baseline period. However, after the present intervention, it was possible to observe improvement upon the evaluated sleep variables.

We observed improvement in the total time awake (decrease), sleep latency (decrease) and total sleep time (increase). Sleep is a fundamental biological component for cognition, energy restoration and brain energetic metabolism. ${ }^{23}$ In relation to the rhythm wake-sleep, for example, during the REM, there is cognitive restoration (learning and memory) ${ }^{24}$ as well as, peaks of release of testosterone hormone..$^{25}$ During Non-REM sleep (NREM), there is huge release of the growth hormone $(\mathrm{GH})$ promoting tissue restitution and several other benefits, ${ }^{23}$ which demonstrates the importance of the night sleep for the consolidation of the biological processes, mainly in athletes. Although sleep reestablishes psychological, cognitive and physiological functions that are considered critical for a best recovery and psychomotor performance, other behavioral and environmental situations might interfere on athletes' sleep. ${ }^{21}$ In relation to chronotype, the majority of the athletes (64\%) were classified as indifferent, which facilitated the temporary alteration of the training timetables, without causing many problems for the athletes. The state of entrainment the circadian rhythm is the main factor of performance. ${ }^{26}$ The participant athletes of the present study were preparing themselves for the Olympic Games Rio 2016 and training twice a day, during time of the competition events. With this, the fact of delaying athlete's sleep became fundamental for competitions that were taking place during night. This strategy was part of the intervention that contributed for athlete's preparation for games. 
Scientific literature has suggested light therapy in order to entrain the circadian rhythm, delaying or advancing the phase of the sleep-wake cycle. Several studies have reported that single pulses of bright light during determined times, are capable of generating important circadian alterations, ${ }_{1}^{27,28}$ primarily caused by the entrainment of the core temperature phase or the suppression of the release of the melatonin hormone. ${ }^{28}$ The application of light at the beginning of the end of the subjective night/ beginning of morning, promotes the temporal entrainment (delaying or advancing phase) of the sleep-wake cycle. ${ }^{8,9}$ In the present study, the athletes received light at the beginning of the subjective night (biological) with the intent of delaying the biological clock for the competitions.

Literature's reported results have evidentiated improvement upon sporting performance at the beginning of the night. ${ }^{1,5-7}$ In a study conducted with swimmers, it was verified that the performance was better at night for athletes who regularly trained at night, meanwhile, the performance's circadian variation was abolished in individuals who trained only during the morning. ${ }^{5}$ This fact corroborates with the findings of our study, mainly because we conducted the interventions at the same timetable stipulated by the Olympic Games' competition calendar and observed that the results of RT and CT did not suffer any decline. In swimming, these variables are indispensable for speed and power competitions. This way, we can point out that the application of light and the performing of training during the time of the events were able to maintain the times of release and of competition of those athletes in the swimming events, demonstrating therefore the efficacy of this intervention. Light per se, especially the light with short-wavelength (fluorescent light) acts acutely on the increase of the wake state..$^{29}$ Additionally, the adaptations to the training are bigger during the day on which the training is regularly conducted. ${ }^{11}$

Improvements anteriorly reported in the sporting performance during the afternoon and beginning of the night, may be attributed to the manipulation of body temperature ${ }^{11,13}$ or to changes the circadian rhythms. ${ }^{5}$ Moments of major alert and attention, quick response to a stimulus, major muscle strength, better aerobic and anaerobic power, as well as better parameters of flexibility, coincide with the acrophase of core temperature. ${ }^{1,3}$ The elevation of core temperature promotes vasodilation, increases the blood supply to muscles, improving glycolysis, glycogenolysis and muscle strength. ${ }^{30}$ Facing this context, the literature points out that psychomotor performance is influenced by the circadian rhythm of the core temperature. ${ }^{30}$ Therefore, from the point of view of Chronobiology, the entrainment of the circadian rhythm of the core temperature to the time of the targeted event, contributes for the improvement or the maintenance of sporting performance obtained during the daily training sessions and we were able to demonstrate that the interventions of sleep hygiene, light applications and the alteration of the training timetable to coincide with the exact time of swimming competitions, were capable of maintaining the results of RT and CT in the Olympic Games Rio 2016, which may have occurred in function of the physiological alterations and a possible entrainment of the phase.

\section{CONCLUSION}

We concluded that the presented intervention was effective in minimizing any effect of the time of competition upon the performance of RT and CT of elite athletes of the Brazilian swimming team. This way, we suggest that the sporting calendar and the time of the events be considered at the moment of the sporting planning for athletes of the swimming team, in order for the athletes may always be able to express their best sporting performance, not influenced by circadian factors.

\section{ACKNOWLEDGMENTS}

The authors would like to thank Universidade Federal de Minas Gerais (UFMG), Centro de Estudos em Psicobiologia e Exercício (CEPE), Centro Multidisciplinar em Sonolência e Acidentes (CEMSA), FUNDEP/UFMG, CNPq, CAPES, Fundação de Amparo a Pesquisa do Estado de Minas Gerais (FAPEMIG), Comitê Olímpico do Brasil (COB) and Laboratório do Comitê Olímpico do Brasil for support and assistance wtih this research.

All authors declare no potential conflict of interest related to this article

AUTHORS' CONTRIBUTIONS: Each author made significant individual contributions to this manuscript. MTM: and MAMS: theoretical research, data collection, analysis of the results, discussion of the data and writing the manuscript; FVN: collection and discussion of the data, writing the manuscript; JPPR and DFR: data collection, analysis of the results and discussion of the data; LSNF: theoretical research, discussion of the data and writing the manuscript; JJB, SRDP and SCS: theoretical research, analysis of the results, discussion of the data; ST: theoretical research, analysis of the results, discussion of the data and writing the manuscript; AS: theoretical research, data collection, analysis of the results, discussion of the data and writing the manuscript. All authors read and approved the final manuscript.

\section{REFERENCES}

1. Atkinson G, Reilly T. Circadian variation in sports performance. Sport Med. 1996;21(4):292-312.

2. Mizuno K. Human circadian rhythms and exercise: significance and application in real-life situations. J Phys Fitness Sports Med. 2014;3(3):307-15.

3. Reilly T, Edwards B. Altered sleep-wake cycles and physical performance in athletes. Physiol Behav. 2007;90(2-3):274-84

4. Eichner ER. Circadian Timekeepers in Sports. Phys Sports Med. 1988; 16(2):78-85.

5. McGowan CJ, Pyne DB, Thompson KG, Raglin JS, Rattray B. Morning exercise enhances afternoon sprint-swimming performance. Int J Sports Physiol Perform. 2017;12(5):605-11.

6. Rae DE, Stephenson KJ, Roden LC. Factors to consider when assessing diurnal variation in sports performance: the influence of chronotype and habitual training time- of-day. Eur J Appl Physiol. 2015;115(6):1339-49.

7. Rosa JP, Rodrigues DF, Silva A, Simim MA, Costa VT, Noce F, et al. 2016 Rio Olympic Games: can the schedule of events compromise athletes' performance? Chronobiol Int. 2016;33(4):435-40.

8. Golombek DA, Rosenstein RE. Physiology of circadian entrainment. Physiol Rev. 2010;90(3):1063-102.

9. Rüger M, St Hilaire MA, Brainard GC, Khalsa SB, Kronauer RE, Czeisler CA, et al. Human phase response curve to a single $6.5 \mathrm{~h}$ pulse of short-wavelength light. J Physiol. 2013;591(1):353-63.

10. Buxton O, Frank SA, L'Hermite-Balériaux M, Leproult R, Turek FW, van Cauter E. Roles of intensity and duration of nocturnal exercise in causing phase delays of human circadian rhythms. Am J Physiol. 1997:273(3 Pt 1):e536-42

11. Chtourou H, Souissi N. The effect of training at a specific time of day: a review. J Strength Cond Res. 2012;26(7):1984-2005.

12. Baxter C, ReillyT, Polytechnic L, Street B, Liverpool L, ReillyT. Influence of time of day on all-out swimming. Brit J Sport Med. 1983;17(2):122-7.

13. Chtourou H, Hammouda O, Aloui A, Souissi N. Effect of time-of-day on muscle fatigue: a review. J Nov Physiother. 2013;3:(3):1-10.

14. Sargent C, Halson S, Roach GD. Sleep or swim ? Early-morning training severely restricts the amount of sleep obtained by elite swimmers. Eur J Sport Sci. 2014;14(Suppl 1):S310-5.

15. Thun E, Bjorvatn B, Flo E, Harris A, Pallesen S. Sleep, circadian rhythms, and athletic performance. Sleep Med Rev. 2015;23:1-9.
16. Passos GS, Santana MG, Poyares D, D'Aurea CV., Teixeira AA, Tufik S, et al. Chronotype and anxiety are associated in patients with chronic primary insomnia. Braz J Psychiatry. 2017;39(2):183-6.

17. Sargent C, Lastella M, Halson SL, Roach GD. The validity of activity monitors for measuring sleep in elite athletes. J Sci Med Sport. 2016;19(10):848-53.

18. Khalsa curve to single bright light pulses in human subjects. J Physiol. 2003;549(Pt 3):945-52. SB, Jewett $\mathrm{ME}$, Cajochen C, Czeisler CA. A phase response

19. Corbett MA. A potential aid to circadian adaptation: re-timer. Aviat Space Environ Med. 2013;84(10):1113-4.

20. Fullagar HH, Duffield R, Skorski S, Coutts AJ, Julian R, Meyer T. Sleep and recovery in team sport: current sleep-related issues facing professional team-sport athletes. 2015;10(8):950-7.

21. Nédélec M, Halson S, Delecroix B, Abaidia AE, Ahmaidi S, Dupont G. Sleep Hygiene and Recovery Strategies in Elite Soccer Players. Sport Med. 2015;45(11):1547-59.

22. Leeder J, Glaister M, Pizzoferro K, Dawson J, Pedlar C. Sleep duration and quality in elite athletes measured using wristwatch actigraphy. J Sports Sci. 2012;30(6):541-5

23. van Cauter E, Holmback U, Knutson K, Leproult R, Miller A, Nedeltcheva A, et al. Impact of sleep and sleep loss on neuroendocrine and metabolic function. Horm Res. 2007:67(Suppl 1):2-9.

24. Stickgold R, Walker MP. Sleep-dependent memory consolidation and reconsolidation. Sleep Med. 2007:8(4):331-43.

25. Hagenauer $\mathrm{MH}$, Ku JH, Lee TM. Chronotype changes during puberty depend on gonadal hormones in the slow-developing rodent, Octodon degus. Horm Behav. 2011;60(1):37-45.

26. Facer-Childs E, Brandstaetter R. The impact of circadian phenotype and time since awakening on diurnal performance in athletes. Curr Biol. 2015;25(4):518-22.

27. Khalsa $S B$, Jewett $M E_{1}$ Cajochen $C$, Czeisler CA. A phase response curve to single bright light pulses in human subjects. J Physiol. 2003:549(Pt 3):945-52.

28. Kozaki T, Kubokawa A, Taketomi R, Hatae K. Effects of day-time exposure to different light intensities on light-induced melatonin suppression at night. J Physiol Anthropol. 2015;34:27.

29. Cajochen C, Khalsa SB, Wyatt JK, Czeisler CA, Dijk DJ. EEG and ocular correlates of circadian melatonin phase and human performance decrements during sleep loss. Am J Physiol. 1999;277(3 Pt 2):R640-9.

30. Waterhouse J, Drust B, Weinert D, Edwards B, Gregson W, Atkinson G, et al. The circadian rhythm of core temperature: origin and some implications for exercise performance. Chronobiol Int. 2005;22(2):207-25 